\title{
Healthcare Expenditure and Economic Growth: How Important Is the Partnership?
}

\author{
Salim A Bagadeem ${ }^{1} \&$ Moid U Ahmad ${ }^{2}$ \\ ${ }^{1}$ Faculty of Business and Administration Studies, Arab Open University, Saudi Arabia \\ ${ }^{2}$ Asia Pacific Institute of Management, New Delhi, India \\ Correspondence: Salim A Bagadeem, Assistant professor, Faculty of Business and Administration Studies, Arab \\ Open University, Saudi Arabia.
}

Received: July 5, 2020

Accepted: August 13, 2020

Online Published: September 5, 2020

doi:10.5430/rwe.v11n5p297

URL: https://doi.org/10.5430/rwe.v11n5p297

\begin{abstract}
An understanding of the relationship between economic variables and healthcare variables will enable a better policy framework for a country. This study focuses on Gross Domestic Product (GDP), healthcare expenditures (HCE) and Out of Pocket expenses (OOP) using an annual data (2000-2015) from Saudi Arabian economy. The study uses statistical techniques such as unit root test, co-integration, linear regressions, Vector Auto Regressions and mediation technique for analysis.

The research found that healthcare expenditure and GDP are correlated and co-integrated in long term (3-7 years) and that the GDP can be best explained at a lag of 3 years by healthcare expenditure. Mediation analysis revealed that private health expenses mediate the relationship between government health expenditure and national income.
\end{abstract}

Keywords: healthcare, GDP, government investments, out of pocket expenses, econometrics, public health, economic growth

\section{Introduction}

Health of the workforce and health care investments are important determinants in the growth of an economy (Amiri $\&$ Ventelou, 2012) and Lucas (1988) considers human capital as one important input in the production function of an economy. A healthy workforce contributes to the economy (Gupta et al.,2002) and healthcare investments pumps in money in the economy is the rationale for countries worldwide initiating big budget healthcare schemes for their citizens. The underlying objective for such big budget schemes (example: Obamacare in the United States and the AYUSHMAN Bharat scheme in India) is to avail political and economic mileage. Such investments in the economy is expected to boost economic growth as well as improve the health care services in the country (Deaton, 2003). Mushkin (1962) states that health care is an investment as well as a consumption as an individual invests for future medical contingencies and also consumes health care services. Bloom \& Canning (2000) propose that if the labour in an economy is healthy, its incentive to develop new skills and knowledge is higher because they expect to enjoy long term benefits. Thus, the labour force is expected to spend on healthcare and contribute to national income if they see long term benefits. It is additionally validated (WHO report, 2005), that 50\% of divergence in economic growth between developing countries and developed countries is attributed to ill-health and low life expectancy of population.

Economic growth can be explained by models based on economic parameters such as savings (Solow, 1956) or based on non-economic parameters such as population's health. The former models maybe termed as direct models and the later may be termed as indirect models. The relationship between Gross Domestic Product (GDP) and Healthcare expenditures (HCE) have been previously studied by researchers [Newhouse (1977); Erdil \& Yetkiner (2009); Mehrara et al. (2012)] which can be linked to income generation, welfare economics and healthcare policies. Health of the workforce is an important determinant of economic development of a country (Amiri \& Ventelou, 2012). A healthy population means higher productivity and thus higher income per capita, leading to higher GDP. Additionally, if the individual expenses on healthcare increases, it will enhance the output of the healthcare industry, consequently improving GDP. The importance of human capital to economic growth cannot be over emphasized (Lucas, 1988) because it serves as a catalyst to economic development (Elmi \& Sadeghi, 2012). The contribution of 
health expenditure towards economic development originates from the health led growth hypothesis, (Mushkin, 1962). Health of a workforce can be considered as capital by countries, companies and individuals. The healthier is the workforce, the more productive it is and perhaps this is the reason that many researches and debates are focused on public and private investment in health care.

Table 1. Current health expenditure (\% of GDP)

\begin{tabular}{lcc}
\hline Country Name & Coefficient of Variation & Average(\%) \\
\hline Arab World & $11.56 \%$ & 4.09 \\
Middle East \& North Africa & $10.31 \%$ & 4.67 \\
North America & $8.47 \%$ & 14.82 \\
OECD members & $8.66 \%$ & 11.06 \\
Saudi Arabia & $19.51 \%$ & 4.19 \\
\hline
\end{tabular}

Source: World Bank national accounts data

Wang (2015) probed upon the amount of healthcare spending by countries and found that the optimal health care expenditure in a growing economy is $7.55 \%$ of GDP ratio. Analyzing the data for the time period 2000-2016 for different geographies (Table 1), revealed that healthcare expenditure as a percentage of GDP varies widely across the globe. The highest spending on healthcare was found to be in North America which had the lowest variation also for this expenditure. The variation in healthcare spending was found to be on the higher side (19.5\%) for Saudi Arabia, indicating a volatile healthcare policy in the country.

The relationship between healthcare and economic variables has been extensively studied in the context of OECD countries but in the context of MENA countries (Mehrara et al., 2012) it is less explored. The average spending by Saudi Arabia (4.19\% of GDP) on healthcare is much less than OECD countries (11\% of GDP) and the healthcare policy is also volatile (see Table 1). There are hardly any studies on the subject for Saudi Arabia and thus this study aims to bridge the gap and contribute to the literature. The research uses standard statistical techniques (such as Granger Causality, VAR), introduces mediation analysis and uses the concept of income elasticity to add to the novelty of the study.

\section{Literature Review}

The relationship between economic parameters and healthcare parameters has been previously studied by researchers in different context [Erdil \& Yetkiner's (2009) study was based on income levels of countries; Mehrara et al., (2012) focused on health care as a luxury good; Lu et al., (2010) focused on channels of external financing for healthcare; Mushkin (1962) focused on holistic view of healthcare investments; Blomqvist \& Carter (1997) found urbanization as a determinant of accessible modern healthcare].

Shaikh \& Singh (2017) suggest that the health care studies should include all aspects of medical care, should not be restricted to public expenditure or the government sector and should include the private expenditure as borne by the individuals. The work of Newhouse (1977) is considered a seminal work on healthcare expenditures and national income. Studying cross-sectional data for 13 developed countries, he found that income elasticity of health care expenditure is greater than 1, and hence a luxury good. Leu (2000); Parkin et al., (1987) used cross-sectional data for OECD countries and also found that the elasticity of health care expenditure is greater than 1 and it is a luxury good. However, there are few contrary studies also. Mehrara et al. (2012) found that health care is not a luxury good in MENA countries. Another study by Hitiris \& Posnett (1992) used a panel data of 20 OECD countries and found that income elasticity is close to 1 , indicating that it is a non-luxury product. Also, Narayan et al. (2011) concluded that health care is a necessity even in OECD countries.

$\mathrm{Lu}$ et al. (2010) studied the financing aspect of health care expenditure and found a positive relationship between official development aid (ODA) and government spending when the aid is channelized through informal sector while a negative relationship was found when the ODA was channelized through government sector. Serap (2016) found that income is an important factor in explaining the difference in healthcare expenditures amongst developing countries. Mushkin (1962) states that the return on investment from healthcare expenditure is received partly by individual and partly by the society as it is an economic safeguard for both stakeholders. Wang (2015) studied OECD 
countries over the period 1990-2009 and found that if the ratio of health spending to gross domestic product is less than $7.55 \%$ (optimal level), an increase in health spending effectively lead to better economic performance.

In most of the developing countries around the world, total spending on health care is dominated by huge amount of private out-of-pocket health care expenditures (Mohapatra \& Mishra, 2011) where they studied the relationship between capital investment and revenues related to health initiatives and its impact on economic growth in the Indian context (1991-2008). They also found that there is a causal effect of Gross Domestic Product (GDP) on Revenue Expenditure (RE) of healthcare, both, in the short run as well as in the long run. Fedeli (2015) confirmed the presence of a relationship between health care expenditure and GDP. He found that the health expenditure patterns of countries varies from USD 3000 per capita for high-income countries to USD 30 per Capita for poor countries and that the health expenditure to GDP ratio varies from $12 \%$ to $3 \%$. The study conducted by Gerdtham \& Löthgren (2000); Clemente et al. (2004) found a positive co-integrating relationship between real per capita health care expenditure and GDP.

Hansen \& King (1996) used a time-series data of 20 OECD countries and found 'no long-term relationship' between health care expenditure and GDP. Wang \& Rettenmaier (2007) studied data from USA and found that both health care expenditure and GDP are non-stationary, having a co-integrating relationship. Abegaz \& Mohammed (2018) found that the health care expenditure and GDP have a long-term co-integration and that health expenditures were a necessity in Ethiopia. Erdil \& Yetkiner ( 2009) studied causality between national income and healthcare expenditure and found that for low income countries causality flows from income to expenditure and a reverse flow is found for high income countries. Hartwig (2008) found that this effect flows only from income to expenditure and with a positive sign. Kuan (2011) found that health expenditure affects national income positively but the reverse relationship is contrary.

Mohapatra \& Mishra (2011) found a causal effect of GDP on health expenditure. Baltagi \& Moscone (2010) found that health care expenditure and economic growth were linked in the long-run. Kumar et al., (2020) found a bidirectional causality between health expenditure and income for Australian economy. Artekin \& Konya (2020) found a long run relationship between health expenditure and economic growth on a sample of 19 OECD countries. On a contrary sample, Oche \& Mah (2020) studied the same relationship for west African countries and also found a bidirectional causality between health expenditure and gross domestic product per capita. Also, they found that health expenditure in the region is a necessity, and not a luxury. This study focuses on a different geography, the middle east region.

\section{Materials and Methods}

The primary objective of the research is to understand the dynamics between economic growth (GDP) and healthcare expenditure of government (GHE) and individuals (OOP) for effective policy making. Ndedi et al. (2017) used OOP and GHE in their research. The research uses GDP as endogenous dependent variable while GHE and OOP have been taken as exogenous independent variables. Accordingly, three null hypotheses have been prepared.

H01: Government health expenditure does not affect economic growth

(see newhouse, 1972)

H02: Individual health expenditure does not affect economic growth

(see Grossman, 1972)

H03: Government health expenditure and individual health expenditure, together, does not affect economic growth

(see Mushkin, 1962)

The research uses data for the time period 2000-2015 (annual series) and is used at two levels, one, at country level (Kingdom of Saudi Arabia) and two, for the Arabian world which includes members of the League of Arabian States (22 countries including Saudi Arabia). The level 2 data (Arabian world) has been used as industry average for comparative analysis. The variables used and the respective explanations are given in Table 2. Two parameters of healthcare expenditure have been used, one measures public or government's expenditure (GHE) and the other measures out of pocket or individual's health care expenditure (OOP). The description and explanation of variables used in the study have been illustrated in Table 2. Wang (2015); Mohapatra \& Mishra (2011) studied GDP and government healthcare expenditure (GHE). Out of pocket payments/expenses (OOP) refer to the private payments/pre-payments/expenses made by the patients/consumers at the point of service (Shaikh \& Singh, 2017). OOPs should be positively correlated with GDP and if national income increases, individual income should increase, resulting in increased healthcare spending to protect health (Grossman, 1972) or resulting in increase in life style diseases, adding to OOPs expenses (Van de Poel, 2009). 
Table 2. Description of research variables

\begin{tabular}{lll}
\hline Codes and acronyms used & \multicolumn{1}{c}{ Variable and Unit } & \multicolumn{2}{c}{ Description } \\
\hline $\begin{array}{l}\text { GDP or } \\
\text { SAUDI_ARABIA_GDP }\end{array}$ & $\begin{array}{l}\text { Gross } \\
\text { Current U.S. dollars, converted in } \begin{array}{l}\text { Domestic Product } \\
\text { local currency. }\end{array}\end{array}$ & $\begin{array}{l}\text { GDP at purchaser's prices is the sum of } \\
\text { gross value added by all resident } \\
\text { producers in the economy plus any } \\
\text { product taxes and minus any subsidies not } \\
\text { included in the value of the products. }\end{array}$ \\
$\begin{array}{l}\text { GHE or } \\
\text { SAUDI_ARABIA_GHE } \\
\text { OOP or }\end{array}$ & $\begin{array}{l}\text { Domestic general government health } \\
\text { expenditure per capita (current US\$) } \\
\text { Out-of-pocket expenditure per capita } \\
\text { SAUDI_ARABIA_OOP }\end{array}$ & $\begin{array}{l}\text { Health expenditure through out-of-pocket } \\
\text { payments per capita. Out of pocket } \\
\text { payments are spending on health directly } \\
\text { out of pocket by households in each } \\
\text { country. }\end{array}$
\end{tabular}

Source: World Bank national accounts data, and OECD National Accounts data files.

The fundamental economic model used in the research is given as shown in equation 1.

$$
G D P=f \text { (Public expenditure on health; Out of pocket expenditure on health) }
$$

The unit root test (at level and at first difference) is used to study co-integration between healthcare expenditures and GDP. It also uses Granger Causality test (Granger, 1969) to evaluate direction of causality amongst the variables. The research further analyzes correlations, linear regressions and unrestricted Vector Auto Regression (VAR) for further interpretation. Granger Causality test was used by Amiri \& Ventelou (2012) in a similar research while Ahmad \& Premaratne (2018) used VAR in a similar macroeconomic study. Additionally, a meditation analysis has been done to further interpret the dynamics amongst these variables. Eviews 7.0 and SPSS 20.0 softwares were used for data analysis. This paper also tries to analyze the growth rate of income and health care expenditure for Saudi Arabia (Table 3) as used in Xu et al. (2011). Income elasticity of demand of health care products and services have been calculated using the formulae (equation 2) where OOP expenses indicate the demand for health care products.

$$
\text { Income Elasticity }=\% \text { change in OOP expenses } / \% \text { change in Income (GDP) }
$$

\section{Result and Discussion}

A comparison of the growth rate for income and health care expenditure for Saudi Arabia (Table 3) indicated that, during the time period 2000-2015, the average GDP growth rate $(9.5 \%)$ was more than Governments health expenditure $(8.45 \%)$ and out of pocket expenditure (6.5\%). It is also observed that there are years $(2001,2008,2010$ and 2015) when contrary growth took place for GHE and OOP. This is supported by a low correlation between OOP and GHE ( $\mathrm{r}=0.03$ ) which suggests that government's health expenses and private health expenses do not move similarly for Saudi Arabia. The correlation coefficient between GDP and GHE ( $r=0.16)$ and between GDP and OOP $(\mathrm{r}=0.19)$ was found to be positive and significant indicating that the GDP of Saudi Arabia moves in the same direction with GHE and OOP separately, but GHE and OOP amongst themselves are not much correlated. Thus, the combined and individual effect of OOP and GHE on GDP needs to be further studied. Since correlations do not indicate the causal effect and the lag effect, thus regression analysis, lag analysis and causality analysis was subsequently conducted for additional analysis.

Table 3. Growth rates and income elasticity

\begin{tabular}{cccccc}
\hline Year & $\begin{array}{c}\text { Saudi Arabia } \\
(\text { GDP\% })\end{array}$ & $\begin{array}{c}\text { Saudi Arabia } \\
(\text { GHE\% })\end{array}$ & $\begin{array}{c}\text { Saudi Arabia } \\
(\text { OOP\% })\end{array}$ & $\begin{array}{c}\text { Income Elasticity } \\
\text { (OOP) }\end{array}$ & $\begin{array}{c}\text { Income Elasticity } \\
\text { (GHE) }\end{array}$ \\
\hline 2001 & -2.84 & 1.01 & -2.00 & 0.70 & -0.36 \\
2002 & 2.97 & -4.93 & -2.42 & -0.81 & -1.66 \\
2003 & 13.82 & 3.59 & 0.69 & 0.05 & 0.26 \\
\hline
\end{tabular}




\begin{tabular}{cccccc}
\hline 2004 & 19.89 & 3.57 & 6.04 & 0.30 & 0.18 \\
2005 & 26.94 & 19.33 & 6.90 & 0.26 & 0.72 \\
2006 & 14.75 & 18.95 & 10.29 & 0.70 & 1.28 \\
2007 & 10.36 & 1.97 & 14.96 & 1.44 & 0.19 \\
2008 & 24.96 & -8.34 & 17.40 & 0.70 & -0.33 \\
2009 & -17.45 & 18.53 & 9.89 & -0.57 & -1.06 \\
2010 & 23.10 & -3.04 & 5.04 & 0.22 & -0.13 \\
2011 & 27.08 & 36.00 & 3.55 & 0.13 & 1.33 \\
2012 & 9.64 & 17.36 & 11.84 & 1.23 & 1.80 \\
2013 & 1.45 & 11.58 & 3.73 & 2.57 & 7.99 \\
2014 & 1.30 & 18.33 & 5.55 & 4.27 & 14.10 \\
2015 & -13.50 & -7.13 & 5.99 & -0.44 & 0.53 \\
Average & 9.50 & 8.45 & 6.50 & 0.68 & 0.89
\end{tabular}

An income elasticity of less than one indicates a necessity product. Hitiris \& Posnett (1992); Sen (2005) found that that income elasticity of healthcare for OECD countries is less than 1. For Saudi Arabia, the average income elasticity (Table 3 ) was found to be 0.68 for OOP and 0.89 for government's health expenditure (GHE). The low income elasticity, high volatility (Coefficient of variation $=19.5 \%$, Table 1) and low average $(4.19 \%$, Table 1) of health expenditure is a concern for Saudi Arabia. The income elasticity is similar to the findings of (Oche \& Mah, 2020),indicating that the health infrastructure is similar in Middle East and African countries.

Table 4. Basic statistics of variables

\begin{tabular}{ccccccc}
\hline & $\begin{array}{c}\text { Saudi_Arabia } \\
\text { (GDP) }\end{array}$ & $\begin{array}{c}\text { Saudi_Arabia } \\
(\mathrm{GHE})\end{array}$ & $\begin{array}{c}\text { Saudi_Arabia } \\
(\mathrm{OOP})\end{array}$ & $\begin{array}{c}\text { Arabian_World } \\
(\mathrm{OOP})\end{array}$ & $\begin{array}{c}\text { Arabian_World } \\
\text { (GHE) }\end{array}$ & $\begin{array}{c}\text { Arabian_World } \\
\text { (GDP) }\end{array}$ \\
\hline Mean & $4.50 \mathrm{E}+11$ & 477.14 & 111.56 & 68.77 & 124.90 & $1.74 \mathrm{E}+12$ \\
$\begin{array}{c}\text { Coefficient of } \\
\text { Variation }\end{array}$ & $48 \%$ & $46 \%$ & $36 \%$ & $36 \%$ & $45 \%$ & $47 \%$ \\
Observations & 16 & 16 & 16 & 16 & 16 & 16 \\
\hline
\end{tabular}

Source: author's calculations based on sample

The coefficient of variation data for Saudi Arabia (Table 4) is similar to the Arab world figures for income and health expenditures, indicating that the performance has been similar to the industry average of Arab world. For Saudi Arabia, the coefficient of variation was observed as highest for GDP (48\%) and lowest for OOP (36\%) indicating a volatile economic growth and comparatively more stable (and growing) out of pocket expenses.

Table 5. Univariate regression (Dependent variable: GDP)

\begin{tabular}{llll}
\hline Independent variable & R-squared(\%) & p-value & Coefficient \\
\hline OOP & 91 & 0 & $5.08 \mathrm{E}+09$ \\
\hline
\end{tabular}

Table 6. Univariate regression (Dependent variable: GDP)

\begin{tabular}{llll}
\hline Independent variable & $\mathrm{R}$-squared(\%) & $\mathrm{p}$-value & Coefficient \\
\hline GHE & 84 & 0 & $8.91 \mathrm{E}+08$ \\
\hline
\end{tabular}


Table 7. Multivariate regression (Dependent variable: GDP)

\begin{tabular}{llll}
\hline Independent variable & R-squared(\%) & p-value & Coefficient \\
\hline OOP & 91 & 0 & $4.31 \mathrm{E}+09$ \\
GHE & & 0.54 & $1.49 \mathrm{E}+08$ \\
\hline
\end{tabular}

Analyzing the regressions (Tables 5, 6), the variance in Saudi Arabia's GDP was found to be effectively explained by OOP $(\mathrm{R}$-squared $=91 \%$, $\mathrm{p}$-value $=0$ ) and GHE $(\mathrm{R}$-squared $=84 \%$, $\mathrm{p}$-value $=0)$ in single variable regressions. A multi variable regression explained $91 \%$ of the variance in GDP (Table 7, statistically significant with no multicollinearity) by OOP ( $p$-value $=0$ ) and GHE ( $p$-value $=0.54$ ) as the two independent variables. The OOP was found to be statistically significant in the single variable regression (Table 5) and bivariate regression (Table 7), indicating the importance of OOP to economic growth of Saudi Arabia. Since the regression coefficients were observed as positive, it indicates that if government spending increases or individuals spend more on health expenditure, the GDP will increase. This also indicates that health care is an important determinant of Saudi Arabia's economic growth. A positive (statistically significant) regression coefficients was found between GHE and OOP (R-squared=89\%) indicating that government and private health expenditures may explain each other but they do not move together (correlation $=0.03$ ). Thus, it can be deduced that if government investment increases, private investment will also increase and both will have a positive effect on economic growth. Considering the results from regression analysis (Tables 5, 6, 7), all the three null hypothesis were rejected.

H01: Government health expenditure does not affect economic growth (Not accepted)

H02: Individual health expenditure does not affect economic growth (Not accepted)

H03: Government health expenditure and individual health expenditure, together, does not affect economic growth (Not accepted)

Table 8. Results from Augmented Dickey Fuller tests

\begin{tabular}{lll}
\hline Variable & At level & At first difference \\
\cline { 2 - 2 } & Not rejected & Not rejected \\
GHE & Not rejected & Rejected \\
OOP & Not rejected & Not rejected \\
\hline
\end{tabular}

Source: Author's compilation

If a time series is stationary, forecasting is supposed to be better. The Augmented Dickey Fuller test (ADF) evaluates for the null hypothesis of 'non-stationary'. Only GHE was found to be stationary at first difference of data (Table 8), in sync with Wang \& Rettenmaier (2007). Analyzing causality for the variables at an optimum lag of 3, only GHE was found to Granger cause GDP for Saudi Arabia (Table 9). This is contrary to (Kiymaz et al., 2006).

Table 9. Results from Granger Causality test

\begin{tabular}{lcc}
\hline Null Hypothesis: & F-Statistic & Probability \\
\hline SAUDI_ARABIA_GHE does not Granger Cause SAUDI_ARABIA_GDP & 4.67 & 0.05 \\
SAUDI_ARABIA_GDP does not Granger Cause SAUDI_ARABIA_GHE & 2.39 & 0.17 \\
SAUDI_ARABIA_OOP does not Granger Cause SAUDI_ARABIA_GDP & 0.90 & 0.49 \\
SAUDI_ARABIA_GDP does not Granger Cause SAUDI_ARABIA_OOP & 1.44 & 0.32 \\
SAUDI_ARABIA_OOP does not Granger Cause SAUDI_ARABIA_GHE & 2.79 & 0.13 \\
SAUDI_ARABIA_GHE does not Granger Cause SAUDI_ARABIA_OOP & 0.84 & 0.52 \\
\hline
\end{tabular}

Initially regression analysis (univariate and multivariate) was conducted at level with GDP as dependent variable along with GHE and OOP as independent variables (Tables 5,6,7). However, since economic variables have a lag 
effect, unrestricted Vector Auto Regression (VAR), based on Sims (1980) was subsequently conducted (Table 10). The VAR system was found to be optimum (Akaike Information Criteria, 1981) at a lag of 3 years.

Table 10. Results from VAR system (Dependent variable: GDP)

\begin{tabular}{lccc}
\hline & $\begin{array}{c}\text { Saudi_Arabia } \\
(\text { GDP })\end{array}$ & $\begin{array}{c}\text { Saudi_Arabia } \\
(\text { GHE })\end{array}$ & $\begin{array}{c}\text { Saudi_Arabia } \\
(\text { OOP })\end{array}$ \\
\hline SAUDI_ARABIA_GDP(-1) & -0.29 & $1.76 \mathrm{E}-09$ & $-3.80 \mathrm{E}-11$ \\
SAUDI_ARABIA_GDP(-2) & -2.98 & $2.84 \mathrm{E}-09$ & $-3.25 \mathrm{E}-10$ \\
SAUDI_ARABIA_GDP(-3) & -2.71 & $2.93 \mathrm{E}-09$ & $-2.94 \mathrm{E}-10$ \\
SAUDI_ARABIA_GHE(-1) & $2.08 \mathrm{E}+09$ & -1.28 & 0.21 \\
SAUDI_ARABIA_GHE(-2) & $1.89 \mathrm{E}+09$ & -1.60 & 0.17 \\
SAUDI_ARABIA_GHE(-3) & $-1.89 \mathrm{E}+09$ & 0.03 & -0.03 \\
SAUDI_ARABIA_OOP(-1) & $1.40 \mathrm{E}+10$ & -26.86 & 2.72 \\
SAUDI_ARABIA_OOP(-2) & $3.45 \mathrm{E}+10$ & -8.88 & 2.45 \\
SAUDI_ARABIA_OOP(-3) & $-2.75 \mathrm{E}+10$ & 18.04 & -2.70 \\
Constant & & 807.7 & -62.81 \\
$R$-square & $-5.70 \mathrm{E}+11$ & 0.99 & 0.99 \\
Adjusted $R$-square & 0.98 & 0.97 & 0.98 \\
\hline
\end{tabular}

Considering lag effects of GHE and OOP, the VAR system was also able to explain 98\% variance in Saudi Arabian GDP and this explained variance was slightly better for GHE (99\%) and OOP (99\%) VAR system. The forecasting efficiency of a VAR system can be understood by analyzing its impulse responses (Chart 1) and decompositions of forecast error variances (Table 11). Chart 1 indicates the effect of one standard deviation shocks of one variable on the other variable. The shock of Saudi Arabian GHE was observed in long term over Saudi Arabian GDP and was found to be fluctuating. The shock of Saudi Arabian OOP was also observed in long term over Saudi Arabian GDP and was found to be positive and rising for three to eight time periods and subsequently came down. These findings further validate the significance of lag effect in the analysis. 
Response to Cholesky One S.D. Innovations

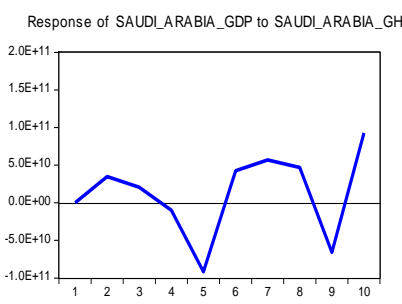

Response of SAUDI_ARABIA_GDP to SAUDI_ARABIA_OOF

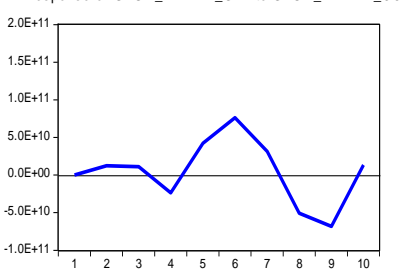

Response of SAUDI ARABIA GHE to SAUDI ARABIA GDP

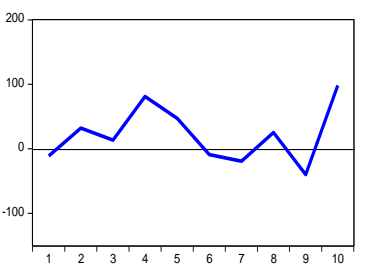

Response of SAUDI_ARABIA_GHE to SAUDI_ARABIA_OOP

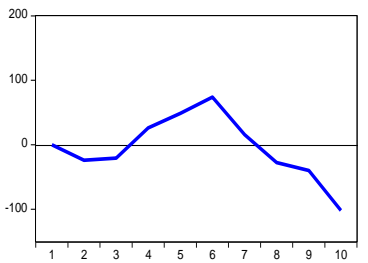

Response of SAUDI_ARABIA_OOP to SAUDI_ARABIA_GDP

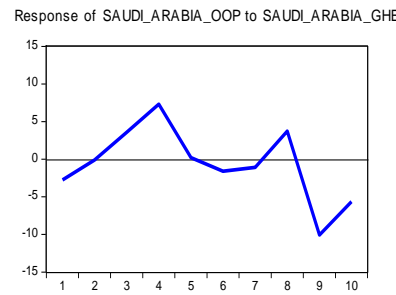

Chart 1. Impulse response functions

Table 11. Variance decomposition (\%) of Saudi Arabia (GDP) based on Cholesky ordering

\begin{tabular}{cccc}
\hline Period & $\begin{array}{c}\text { Saudi_Arabia } \\
(\text { GDP })\end{array}$ & $\begin{array}{c}\text { Saudi_Arabia } \\
(\text { GHE })\end{array}$ & $\begin{array}{c}\text { Saudi_Arabia } \\
(\text { OOP })\end{array}$ \\
\hline 1 & 100 & 0.0 & 0.0 \\
2 & 72.39 & 24.50 & 3.11 \\
3 & 72.09 & 23.86 & 4.05 \\
4 & 72.43 & 18.65 & 8.92 \\
5 & 48.11 & 41.19 & 10.70 \\
6 & 40.89 & 34.64 & 24.47 \\
7 & 36.53 & 39.15 & 24.31 \\
8 & 44.45 & 32.86 & 22.69 \\
9 & 56.91 & 24.37 & 18.70 \\
10 & 52.17 & 30.74 & 17.08 \\
\hline
\end{tabular}

Analyzing variance decompositions in forecasting (Table 11), Saudi Arabian GDP was found to be more effected by GHE and OOP as time period increases and this effect was observed as maximum in seventh year, in concurrence to the impulse responses.

A mediation analysis was further conducted to explore more about the interrelationship between expenditures and income by applying regression based mediation technique. It is observed (see Table 12) that in a multivariate regression, in the presence of OOP, GHE became insignificant ( $\mathrm{p}$-value $=0.55$ ) indicating that OOP mediates the relationship between GHE and GDP. This mediation effect was calculated as 91\% (Mediation effect/Total effect). 
Table 12. Regression results

\begin{tabular}{llll}
\hline Dependent variable & Independent variable & $R$-square (\%) & $p$-value \\
\hline GDP & GHE & 84 & 0.0 \\
GDP & OOP & 91 & 0.0 \\
OOP & GHE & 89 & 0.0 \\
GDP & OOP,GHE & 91 & 0.0 \\
\hline
\end{tabular}

\section{Conclusion}

The research was conducted with an objective to understand the dynamics between healthcare expenditures and the economic growth with a focus on Saudi Arabia, enabling better policy making. The overall conclusion is that the Saudi Arabian economy is largely dependent on government and individual healthcare expenditures and that its healthcare policy is not stable and sufficient. The low income elasticity, high volatility (19.5\%, Table 1) and low average $(4.19 \%$, Table 1$)$ of health expenditure is a concern for Saudi Arabia.

Analyzing the linear regressions (at level), it was found that the variance in Saudi Arabia's GDP was 91\% explained by OOP, $84 \%$ explained by GHE and $91 \%$ explained by a combination of OOP and GHE. The three null hypotheses (H01,H01,H03) were rejected indicating that the national income for Saudi Arabia does depend upon public and private health expenditures.

Considering the importance of lag effect on economic time series analysis, the optimum lag was found to be three years and the highest explained variance in forecasts for GDP was found to be for seventh year for OOP and GHE. Thus, the effect of government expenditure in health care (GHE) and individual expenditure in health care (OOP) can be observed and optimized for a time period of 3-7 years on the national income (see Baltagi \& Moscone,2010). The impact of statistical impulses for Saudi Arabian OOP on Saudi Arabian GDP was found to increase after three time periods and came down after eight time periods. This further validates the optimum lag effect of three to seven time years for this economic dynamics. Causality analysis indicated that the government health expenditure causes national income at a lag of three years.

Further confirmation of the economic relationship for Saudi Arabia was done through mediation analysis where it was observed that out of pocket healthcare expenditures (OOP) mediates ( $91 \%$ effect) the effect of government expenditures (GHE) on national income (GDP). This further emphasizes the importance and need of private investment in the healthcare sector in the country which will further boost national income through private consumption of healthcare services.

\subsection{Managerial Implications}

The private providers of healthcare products and services should use these findings (VAR system and multivariate regression) to predict national income and government expenditure in healthcare and accordingly plan their investment in the economy (see Abegaz \& Mohammed,2018). One such mathematical model (based on equation 1) is equation 3, which is customized for Saudi Arabia but can provide suggestions to other countries. The VAR model (equation 3, adjusted R-square $>90 \%$ ) can be generalized and can be used by any country across the globe.

$$
G D P=0.15 * G H E+0.81 * O O P
$$

The income elasticity for Saudi Arabia was found to be on the lower side and thus, the government as well as the healthcare companies in Saudi Arabia need to work to improve this income elasticity. Since income is growing at a rate of $9.5 \%$ per annum, and if income elasticity further increases, it is expected that the government and customer would spend more on healthcare. The country's policymakers may use this information to improve health care investments by government as well by individuals which will result in better economic growth (GDP), better healthcare facilities and better health of the workforce.

\subsection{Limitations}

The data available on the World Bank database is not updated for current year and hence the dataset used as per the availability of data. Although the focus of the study is Saudi Arabia but the findings can be generalized to other countries also. The sample could be expanded to other GCC countries in future studies.

\section{References}

Abegaz, K. H., \& Mohammed, A. A. (2018). Healthcare expenditure and GDP in Ethiopia from 1995 to 2014: a time-series analysis. Agriculture \& Food Security, 7, 47. 
Ahmad, M. U., \& Premaratne, H. A. G. (2018). Effect of Low and Negative Interest Rates: Evidence from Indian and Sri Lankan Economies. Business Perspective and Research, 6(2), 90-99.

Akaike, H. (1981). Likelihood of a Model and Information criteria. Journal of Econometrics, 16(1), 3-14.

Amiri, A., \& Ventelou, B. (2012). Granger causality between total expenditure on health and GDP in OECD: evidence from the Toda-Yamamoto approach. Economics Letters, 116, 541-544.

Artekin, A. O., \& Konya, S. (2020). Health Expenditure and Economic Growth: Is The Health led Growth Hypothesis Supported For Selected OECD Countries?. Business Excellence, 14(1), 77-89.

Baltagi, B. H., \& Moscone, F. (2010). Health care expenditure and income in the OECD reconsidered: Evidence from panel data. Economic Modelling, 27(4), 804-811.

Blomqvist, A. G., \& Carter, R. (1997). Is health care really a luxury?. Journal of Health Economics, 16, 207-236.

Bloom, D. E., Canning, D., \& Malaney, P. N. (2000). Population Dynamics and Economic Growth in Asia. Population and Development Review, 26, 257-290.

Clemente, J., Marcuello, C., Montañés, A., \& Pueyo, F. (2004). On the international stability of healthcare expenditure functions: are government and private functions similar?. Journal of Health Economics, 23(3), 589-613.

Deaton, A. (2003). Health, inequality and economic development. Journal of Economic Literature, 41(1), 113-158.

Elmi, Z. M., \& Sadeghi, S. (2012). Health care expenditures and economic growth in developing countries: panel co-integration and causality. Middle-East Journal of Scientific Research, 12(1), 88-91.

Erdil, E., \& Yetkiner, I. H. (2009). The Granger-causality between health care expenditure and output: a panel data approach. In Applied Economics (pp. 511-518). Taylor \& Francis.

Fedeli, S. (2015). The Impact of GDP on Health Care Expenditure: The Case of Italy (1982-2009). Social Indicators Research: An International and Interdisciplinary Journal for Quality-of-Life Measurement, 122(2), 347-370.

Fuhmei, W. (2015). More Health Expenditure, Better Economic Performance? Empirical Evidence from OECD Countries. Inquiry, 52, 1-5.

Gerdtham, U. G., \& Löthgren, M. (2000). On stationarity and cointegration of international health expenditure and GDP. Journal of Health Economics, 19(4), 461-75.

Granger, C. W. J. (1969). Investigating causal relation by econometric and cross-sectional method. Econometrica, 37, 424-438.

Grossman, M. (1972). On the concept of health capital and the demand for health. Journal of Political Economy, 80(2), 223-55.

Gupta, S., Verhoeven, M., \& Tiongson, E. R. (2002). The effectiveness of government spending on education and health care in developing and transition economies. European Journal of Political Economy, 18(4), 717-37.

Hansen, P., \& King, A. (1996). The determinants of health care expenditure: a co-integration approach. Journal of Health Economy, 15(1), 127-37.

Hartwig, J. (2008). What drives health care expenditure?--Baumol's model of unbalanced growth revisited. Journal of Health Economics, 27(3), 603-623.

Hitiris, T., \& Posnett, J. (1992). The determinants and effects of health expenditure in developed countries. Journal of Health Economics, 11(2), 173-81.

Kiymaz, H., Akbulut, Y., \& Demir, A. (2006). Tests of stationarity and cointegration of health care expenditure and gross domestic product: an application to Turkey. European Journal of Health Economics, 7(4), 285-294.

Kuan M. W. (2011). Health care expenditure and economic growth: Quantile panel-type analysis. Economic Modelling, 28(4), 1536-1549.

Kumar, R. R., Stauvermann, P. J., \& Shahzad, S. J. H. (2020). Nexus between energy consumption, health expenditure and economic growth in Australia. International Journal of Oil, Gas and Coal Technology, 24(4), 543-572.

Leu, R. E. (1986). The public-private mix and international health care cost. In Culyer, A. J., \& Jonsson. B. (Eds.), Public and Private Healthcare Services (pp. 41-63). Basil Blackwell: Oxford, UK. 
Lu, C., Schneider, M. T., Gubbins, P., Katherine, L. K., Jamison, D., \& Murray, C. (2010). Public financing of health in developing countries: a cross-national systematic analysis. The Lancet, 375, 1375-1387.

Lucas, R. (1988). On the Mechanics of Economic Development. Journal of Monetary Economics, 22(1), 3-42.

Mehrara, M., Fazaeli, A. A., Fazaeli, A. A., \& Fazaeli, A. R. (2012). The Relationship between Health Expenditures and Economic Growth in Middle East \& North Africa (MENA) Countries. International Journal of Business Management, Economics and Resesrch, 3(1), 425-428.

Mohapatra, S., \& Mishra, P. (2011). Composition of Public Expenditure on Health and Economic Growth: A Co-integration Analysis and Causality Testing. IUP Journal of Public Finance, 9(2), 30-43.

Mushkin, S. (1962). Health as an Investment. Journal of Political Economics, 70(5), 129-157.

Narayan, P. K., Narayan, S., \& Smyth, R. (2011). Is health care really a luxury in OECD countries? Evidence from alternative price deflators. Applied Economics, 43(25), 3631-3643.

Ndedi, A. A., Metha, A., \& Nisabwe, F. (2017). The impact of health expenditures on economic growth of Cameroon: A literature review perspective. Retrieved from www.ssrn.com/abstract $=3036510$

Newhouse, J. P. (1977). Medical-care expenditure: a cross-national survey. Journal of Human Resources, 12(1), $115-25$.

Oche, M. O., \& Mah, G. (2020). A panel analysis of health expenditure and economic growth in ECOWAS countries. African Journal of Business and Economic Research, 15(1), 55-82.

Parkin, D., McGuire, A., \& Yule, B. (1987). Aggregate health care expenditures and national income: is health care a luxury good?. Journal of Health Economy, 6(2), 109-27.

Sen, A. (2005). Is health care a luxury? New evidence from OECD data. International Journal of Health Care Finance and Economics, 5(2), 147-164.

Serap, B. (2016), Healthcare Expenditure and Economic Growth in Developing Countries. Advances in Economics and Business, 4(2), 76-86.

Shaikh, I., \& Singh, S. (2017). On the examination of out-of-pocket health expenditures in India, Pakistan, Sri Lanka, Maldives, Bhutan, Bangladesh and Nepal. Business: Theory \& Practice, 18(1), 25-32.

Sims, C. A. (1980). Macroeconomics and reality. Econometrica, 48(1), 1-48.

Solow, R. (1956). A contribution to the theory of economic growth. The Quarterly Journal of Economics, 70(1), 65-94.

Van de Poel, E., O’Donnell, O., \& Van Doorslaer, E. (2009). Urbanization and the spread of diseases of affluence in China. Economy and Human Biology, 7(2), 200-216.

Wang, Z., \& Rettenmaier, A. J. (2007). A note on co-integration of health expenditures and income. Health Economics, 16(6), 559-78.

World Health Organisation. (2005). Make every mother and child count. The World Health Report.

Xu, K., Saxsena, P., \& Holly, A. (2011). The determinants of Health Expenditure: A country level panel data analysis. Working Paper: Results for Development Institute.

\section{Notes}

Note 1. OECD is Organization for Economic Co-operation and Development

Note 2. KSA is Kingdom of Saudi Arabia or Saudi Arabia

Note 3. GCC Gulf cooperation countries

\section{Copyrights}

Copyright for this article is retained by the author(s), with first publication rights granted to the journal.

This is an open-access article distributed under the terms and conditions of the Creative Commons Attribution license (http://creativecommons.org/licenses/by/4.0/). 